\title{
Supply Response Analysis of Rice Growers in District Gujranwala, Pakistan
}

\author{
Sunair Junaid1, Arif Ullah², Shaofeng Zheng'2, Syed Noor Muhammad Shah ${ }^{3,4 *}$, \\ Shahid Ali', Munir Khan' ${ }^{1}$ \\ ${ }^{1}$ Department of Agricultural and Applied Economics, The University of Agriculture, Peshawar, Pakistan \\ ${ }^{2}$ College of Economics and Management, Northwest A \& F University, Yangling, China \\ ${ }^{3}$ Department of Horticulture, Faculty of Agriculture, Gomal University, D. I. Khan, Pakistan \\ ${ }^{4}$ College of Horticulture, Northwest A \& F University, Yangling, China \\ Email: noor.aup@gmail.com
}

Received 31 July 2014; revised 31 August 2014; accepted 23 September 2014

Copyright (C) 2014 by authors and Scientific Research Publishing Inc.

This work is licensed under the Creative Commons Attribution International License (CC BY).

http://creativecommons.org/licenses/by/4.0/

(c) (i) Open Access

\begin{abstract}
The study was designed to estimate the restricted profit function in district Gujranwala, Punjab, Pakistan. Data were collected from 100 respondents using proportional allocation sampling technique. The analysis was done using SHAZAM software. The results indicate that the farmers are price-responsive. Rice own price elasticity was 1.873 . The output supply elasticity of rice with respect to education, land, fertilizer price and irrigation cost were $0.0 .169,1.274,-0.873$ and -0.953 respectively. Irrigation demand elasticity with respect to education, land, fertilizer price, irrigation cost and output price were $0.14,1.14,-0.783,-1.84$ and 1.78 respectively. Fertilizer demand elasticity with respect to education, land, fertilizer price, irrigation cost and output price was $0.023,0.792,-1.65,-0.85$ and 1.851 respectively. Lastly, the elasticity of profit with respect to education, land, fertilizer price, irrigation cost and output price was $0.20,1.10,-0.83,-1.136$ and 1.92 respectively. The study recommends that Government should provide consistent electricity with stable rates, so that, they irrigate their fields through electric tube wells and ultimately their cost of irrigation decreases. The study also suggests that government should stabilized fertilizer prices to encourage its application. Furthermore, government should raise procurement price of rice to encourage its supply this; it in turn will also increase the profit of the farmer.
\end{abstract}

\section{Keywords}

Rice, Supply Response, Translog Restricted Profit

\footnotetext{
${ }^{*}$ Corresponding author.
} 


\section{Introduction}

Agriculture is back bone of economic growth and development in Pakistan. Being the dominant sector, it contributes $21.4 \%$ to GDP, employs $45 \%$ of the country's labour force and contributes in the growth of other sectors of the economy. The healthy expansion in agriculture stimulates domestic demand for industrial goods and other services and supplying raw material to agro-based industry notably cotton textile industry which is the largest subsector of manufacturing sector [1].

Rice is staple food worldwide, particularly in "East, South, Southeast Asia, the Middle East, Latin America, and the West Indies". It ranked second in production worldwide after maize crop. The world top ten producing countries are "China, India, Indonesia, Bangladesh, Vietnam, Thailand, Burma, Philippines, Brazil, and United States of America”. The other minor producers of Rice are Japan, Cambodia, Pakistan, Republic of Korea, Madagascar, Nigeria, Egypt, and Sri Lanka [2]. Rice plays a significant role in agrarian economy of the Pakistan. Pakistan is considered as main rice exporter with share of world trade of $10 \%$, which is about 2 million tons annually. Share of Pakistani basmati rice in export is $25 \%$ managed by private traders [3]. The main competitors of Pakistani rice are Thailand, India and Chad. The government of Pakistan has taken effective measures to increase the production and quality of export rice. That's why research efforts are continuing on developing high yielding basmati and IRRI varieties. Emphases are also being laid on agronomic research like fertilizer use, direct seedling etc. and on improved extension services. The flow of input and credits is also being substantially increased [4].

The importance of estimating valid elasticities of farm output supply and input demand can hardly be overemphasized [5]. Reliable estimates of the responsiveness of the supply of and demand for agricultural products to prices and other factors are fundamental to accurate economic forecasting and valid policy decision making. For example, own-price elasticities of demand indicate the extent to which buyers vary their purchases as the price of the product rises or falls. These variations are measured as movements along the demand curve. Crossprice elasticities of demand provide a framework for understanding the interactions in food and fibre choice decisions by consumers. These are reflected in shifts in the location of demand curves. This understanding is necessary for the accurate analysis of the response of consumers to changes in prices of products due to changes in their external environment [6].

The policy analyses which evaluate the impact of changes in single price or non-price variables or combinations of them become available. Due to resulted both the price elasticities and the elasticities with respect to several other variables that are usually considered as constraints on farm production for the elasticity estimates of input demand and output supply [7]. Technological change and positive price policy can play a significant role in stimulating agricultural production through the desired allocation of resources. At these stages, the policy planners face the challenges to formulate suitable agricultural policy by which the desired growth of agricultural output can be achieved. In order to formulate effective price policy, one needs reliable empirical knowledge about the degree of responsiveness of demand for factors and supply of products, to reliable prices and technological changes. The output supply and factor demand are closely interlinked to each other. Therefore, any change in factor and product prices affects the factor demand and output supply simultaneously. Rising cost of inputs discourages the input use and reduces the output supply. The decline in output supply raises food prices [8].

The literature suggests that production target achieved by providing very high support prices. As these high support prices may not practicable for Government, a more particular option is to bring more land area under rice crop and this area also allocated under modern rice varieties [9].

The study results are likely to be essential used for different reasons. For farm output supply reliable evaluation should be made by using input demand elasticities, are of enormous importance for the accurate prediction of the responsiveness of farmers to changes in input-output prices and government taxes and therefore used intensive programs to create the national requirement of development and food exports in agricultural sector. Results of the coefficient of elasticity may distribute a solid foundation in the development of effective policies applicable to the intrusion to support production, equity, efficiency and circulation revenues finally free in the agricultural sector of the economy.

The purpose of this paper is to apply the normalized restricted translog profit function and the corresponding system of derived demand equations to the farm-level data for rice from three villages of district Gujranwala, Pakistan in order to generate policy-relevant empirical estimates for rice supply and input demand function. The 
study addresses some of the issues that need to be confronted in determining what adjustments might be appropriate. In particular, the study explores the response of rice producers in district Gujranwala of Pakistan, to changes in prices and fixed inputs.

\section{Methodology}

\subsection{Data Collection and Sampling}

A multistage sampling technique was used for the selection of sampled respondents. Various stages are involved in collection of data through multistage sampling technique. In the first stage district Gujranwala was purposively selected as it is the second largest rice producing district of Punjab province, Pakistan. In stage 2, out of five tehsils (Gujranwala City, Gujranwala Sadar, Kamonki, NowshehraVirkan and Wazirabad) one tehsil (Gujranwala City) was randomly selected through simple random sampling technique. In third stage, three villages were randomly selected from a list of major rice producing villages of Gujranwala City. And then in the fourth and last stage a sample size of 100 respondents were randomly selected from selected villages through proportional allocation sampling technique. Data collected for this study openly from farmers through face to face discussion. The collected data were entered in tally sheets of computer software EXCEL and SHAZAM. Various analyses of the data were presented in the tabulated form.

\subsection{Specification of Empirical Model}

The Normalized Restricted Translog Profit Function Approach was used, as formulated by Diewert [10] and Christensen, et al. [11].

$$
\begin{aligned}
\ln \Pi_{R}^{*} & =\alpha_{0}+\alpha_{i} \sum_{i=1}^{2} \ln p_{i}^{*}+1 / 2 \sum_{i=1}^{2} \sum_{j=1}^{2} \gamma_{i j} \ln p_{i}^{*} \ln p_{j}+\sum_{i=1}^{2} \sum_{k=1}^{2} \delta_{i k} \ln p_{i}^{*} \ln z_{k} \\
& +\sum_{k=1}^{2} \beta_{k} \ln z_{k}+1 / 2 \sum_{k=1}^{2} \sum_{k=1}^{2} \theta_{k h} \ln z_{k} \ln z_{h}+\varepsilon
\end{aligned}
$$

where

$\Pi_{R}^{*}=$ Restricted profit, $\Pi_{R}$, normalized by the output price $\left(P_{R}\right)$.

$P_{i}^{*}=$ Price of ith input $\left(P_{i}\right)$ normalized by the output price $\left(P_{R}\right)$.

$i=j=1$, Irrigation.

$=2$, Fertilizer.

$Z_{k}=$ Quantity of fixed input, $k$.

$k=h=1$, Area under rice crop.

$=2$, Average no. of schooling years per male family member above 13 years.

$\alpha_{0}, \alpha_{i}, \gamma_{i j}, \delta_{i k}, \beta_{k}$ and $\theta_{k h}$ are parameters to be estimated.

$E=$ Random error.

For econometric estimation, irrigation and fertilizer were used as variable inputs and land under rice crop and education as fixed inputs. These variables are defined as below:

1) Restricted profit: It is calculated by excluding cost of irrigation plus fertilizer cost from total revenue and then normalized/divided by output price.

2) Irrigation: In profit function irrigation input is used consist of per acre irrigation cost and then normalized/divided by output price. It is represented by $P_{\text {Ig }}$ in the model.

3) Fertilizer: Fertilizer input used in equation is calculated as per kilogram price in rupees per acre, it is actually the total cost of different fertilizer converted in kilograms and then normalized or divided by output price of rice.

4) Land: Land for rice crop is calculated as total land under rice crop it is represented by $Z_{1}$.

5) Education: Education was calculated as total education level of all male family members who were older than 13 and it is represented by " $Z_{2}$ ”.

The corresponding share equations are expressed as,

$$
S_{i}=P_{i} x_{i} / \Pi_{R}=-\partial \ln \Pi^{*} / \partial \ln P_{i}^{*}=-\alpha_{i}-\sum_{j=1}^{2} \gamma_{i j} \ln P_{j}^{*}-\sum_{k=1}^{2} \delta_{i k} Z_{k}
$$




$$
S_{R}=P_{R} x_{R} / \Pi_{R}=1+\partial \ln \Pi^{*} / \partial \ln P_{R}^{*}=1-\sum_{i=1}^{2} \alpha_{i}-\sum_{i=1}^{2} \sum_{j=1}^{2} \gamma_{i j} \ln p_{j}^{*}-\sum_{i=1}^{2} \sum_{k=1}^{2} \delta_{i k} \ln Z_{k}
$$

where $S_{i}$ is the share of $i$ th input, $S_{R}$ is the share of output, $X_{i}$ denotes the quantity of input $i$ and $y_{R}$ is the level of rice output.

Since the input and output shares come from a singular system of equations (since by definition $S_{R}-\Sigma S_{i}=1$ ), one of the share equations, the output share, was dropped and the profit and factor demand equations were estimated as a simultaneous system.

\subsection{Estimation of Elasticities}

Production elasticities were calculated by using following formulae.

\subsection{Input Demand Elasticities}

The own price elasticity of demand for variable input $i\left(\eta_{i i}\right)$, was estimated as:

$$
\eta_{i i}=-S_{i}-\gamma_{i i} / S_{i}-1
$$

where $S_{i}$ is the $i^{\text {th }}$ share equation, at the sample mean.

For the cross-price elasticity of demand for ith variable input with respect to the price of $j$ th variable input $\left(\eta_{i j}\right)$, the following expression was used.

$$
\eta_{i j}=-S_{j}-\gamma_{i j} / S_{i} \quad \text { for } i \neq j
$$

The following equation was used for estimating the elasticity of demand for variable input with respect to output price, $P_{R}\left(\eta_{i R}\right)$

$$
\eta_{i R}=S_{R}+\sum_{j=1}^{2} \gamma_{i j} / S_{i}
$$

The elasticity of demand for variable input with respect to $k$ th fixed factor, $\eta_{i k}$

$$
\eta_{i k}=\beta_{k}+\delta_{i k} \ln \ln P_{i}^{*}+\theta_{k h} \ln Z_{h}-\delta / S_{R}
$$

\subsection{Output Supply Elasticities}

To compute the elasticity of output supply with respect to price of $i^{\text {th }}$ variable input $\left(\epsilon_{R i}\right)$ the following equation was used.

$$
\epsilon_{R i}=-S_{i}-\gamma_{j i} / S_{R}
$$

The own price elasticity $\left(\epsilon_{R R}\right)$ was calculated using the following equation

$$
\epsilon_{R R}=\sum_{i=1}^{2} S_{i}+\gamma_{j i} / S_{R}
$$

The elasticity of output supply with respect to fixed input $k\left(\epsilon_{R K}\right)$ was computed as:

$$
\left(\epsilon_{R K}\right)=\beta_{k}+\sum_{i=1}^{2} \delta_{i k} \ln P_{i}^{*}+\theta_{k h} \ln Z_{h}+\sum_{i=1}^{2} \delta / S_{R}
$$

\subsection{Profit Elasticities}

These are defined as:

$$
\partial \ln \Pi^{*} / \partial \ln P_{i}^{*}
$$

For the elasticity of profit with respect to changes in input prices and

$$
\partial \ln \Pi^{*} / \partial \ln Z_{k}
$$

For the profit elasticity with respect to changes in fixed inputs. 


\section{Results and Discussion}

\subsection{Parameters Estimates of the Normalized Restricted Translog Profit Function}

Estimated factors of the normalized restricted translog profit function and demand equations are entered in the following equations. The estimated parameters of translog profit function and input demand equations are used to calculate the elasticities of input demand and output supply in relation to the price of rice, the amount of fixed and changeable inputs prices.

The following model was estimated empirically:

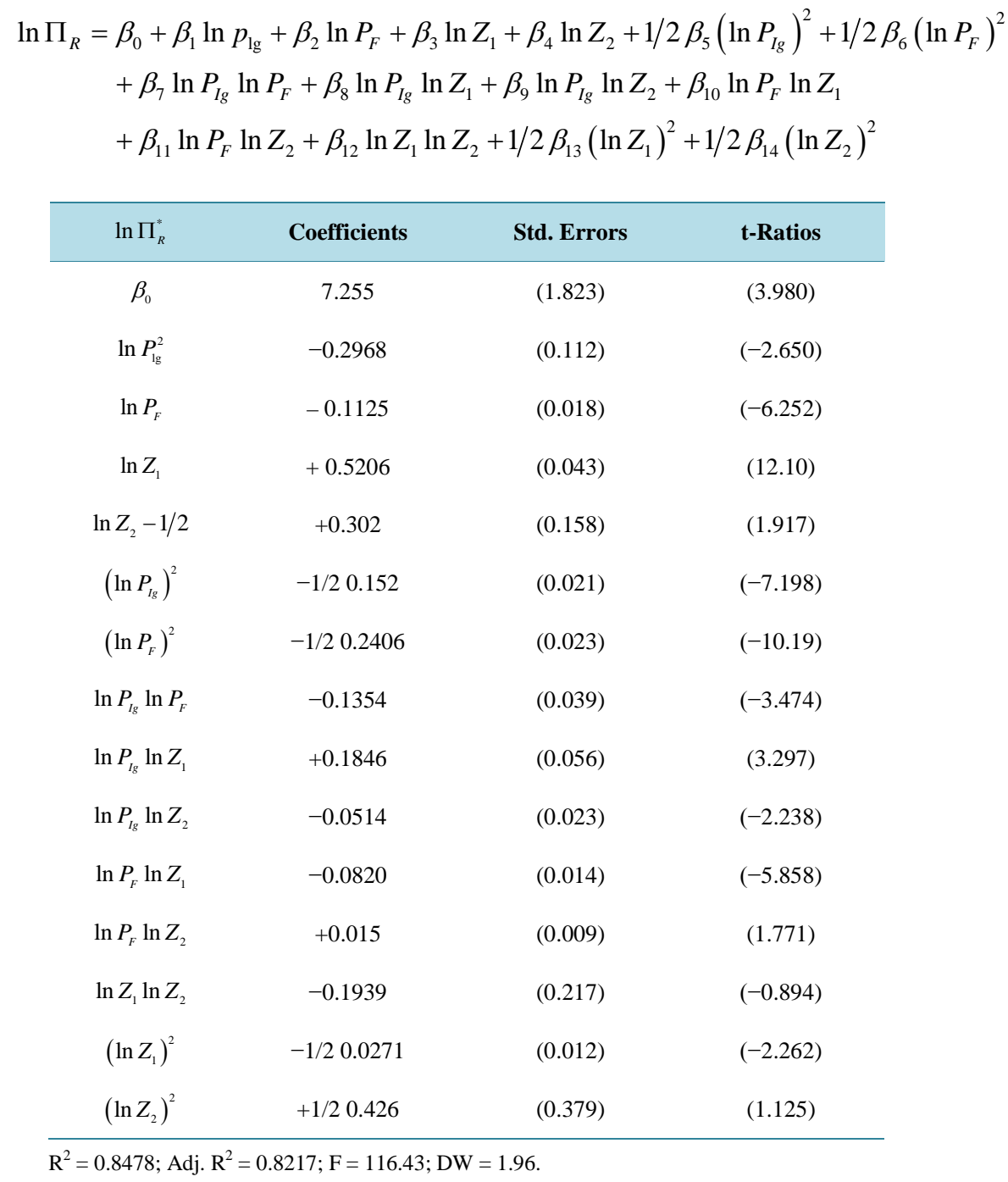

The coefficient of determination value i.e. $R^{2}$ reveals that the independent variable explains $82.1 \%$ of the variation in the dependent variables. The value of $F(116.43)$ shows that the model is good to fit. DW (1.96) shows that there is no auto co-relation problem [12]. The above model was used to calculate the equation of the demand for changeable/variable inputs i.e. irrigation and fertilizer.

\subsection{Factor Demand Equations}

$$
\begin{aligned}
& D_{i g}=\beta_{0}+\beta_{1} \ln P_{I g}+\beta_{2} \ln P_{F}+\beta_{3} \ln Z_{1}+\beta_{4} \ln Z_{2} \\
& D_{f}=\beta_{0}+\beta_{1} \ln P_{I g}+\beta_{2} \ln P_{F}+\beta_{3} \ln Z_{1}+\beta_{4} \ln Z_{2}
\end{aligned}
$$




\begin{tabular}{ccccc}
\hline & & Coefficients & Std. Errors & t-Ratios \\
\hline \multirow{3}{*}{$\boldsymbol{D}_{\boldsymbol{i g}}$} & $\beta_{0}$ & -0.2968 & $(0.112)$ & $(-2.650)$ \\
& $\ln P_{I g}$ & -0.152 & $(0.021))$ & $(-7.198)$ \\
& $\ln P_{F}$ & -0.135 & $(0.039)$ & $(-3.474)$ \\
& $\ln Z_{1}$ & +0.184 & $(0.056)$ & $(3.297)$ \\
& $\ln Z_{2}$ & -0.051 & $(0.023)$ & $(-2.238)$ \\
& $\beta_{0}$ & -0.112 & $(0.018)$ & $(-6.252)$ \\
$\boldsymbol{D}_{f}$ & $\ln P_{I g}$ & -0.135 & $(0.039)$ & $(-3.474)$ \\
& $\ln P_{F}$ & -0.240 & $(0.023)$ & $(-10.194)$ \\
& $\ln Z_{1}$ & -0.082 & $(0.014)$ & $(-5.858)$ \\
& $\ln Z_{2}$ & +0.015 & $(0.009)$ & $(1.77)$ \\
\hline
\end{tabular}

where $D_{I g}$ and $\mathrm{D}_{f}$ shows equation for demand of irrigation and fertilizer respectively. The intercept of both equations were negative. The relationship of irrigation demand with irrigation cost, fertilizer price and education is negative. But positive relationship for land the demand for fertilizer has negative relation with fertilizer price, irrigation cost and land while positive relationship is estimated with education.

\subsection{Descriptive Statistics of the Variable Included in the Analysis}

After detailed interview of the rice growers in the study area results were presented in tabular form (Table 1) which showed that per kg price of rice mean was computed Rs. 39.4/- and its Standard Deviation was Rs. 8.7/and its per acre Irrigation cost mean was found Rs. 21276.7 while Standard Deviation was Rs. 2932.1/-. Furthermore, per Kg price of fertilizer mean was calculated Rs. 37.5/- having Standard Deviation Rs. 10.2/- was figures out. During survey Area under rice was calculated in Acre(s) its mean and Standard Deviation were estimated 8.4 and 5.6 respectively. In addition, for the production analysis Education was estimated in years. The mean value for education was 2.9 and Standard Deviation 1.46. At the end, Restricted Profit mean value was obtained Rs.38666.72 and Standard Deviation share was 10805.01.

\subsection{Calculated Elasticities and Their Accusation}

Table 2 demonstrates the elasticities of input demand and supply of output in relation to price of changeable inputs, rice price and quantity of fixed inputs. Following elasticities were calculated by using translog profit function and equations of input demand.

Farmer feedback for increasing price of rice is positive and elastic in the study area, Surge of price by $1 \%$ of rice boost the output supply of rice increase by 1.873 percent. This Surge in rice prices would also encourage the expansion of direct and significant demand for input variables/changeable inputs. In quantitative terms, the percent surge in demand for irrigation associated with an increased percent of price of rice was 1.780 percent and for fertilizer it was 1.851 percent. Rising price of rice, also increase the net return of farmers in the study area: 1\% increase in rice price, surge profit/net return of 1.920 percent. These results are in conformity with the results obtained by Rahman [13].

The outcomes of the own-price elasticity of demand for changeable inputs are negative, as expected and price elastic. Irrigation demand owns price elasticity is -1.842 . Which shows $1 \%$ rush in the cost of irrigation, decline demand for irrigation by $1.842 \%$. While for fertilizer the own price elasticity is -1.650 , shows that $1 \%$ increase, in the cost fertilizer, decline demand by $1.65 \%$. Similarly the effect of surge in the price of changeable inputs has negative impact on the supply of rice. Increase, in $1 \%$ cost of irrigation, reduce the supply of rice by $0.953 \%$, likewise irrigation, fertilizer costs decreases the supply by $0.873 \%$. In the same way surge in the prices of changeable inputs also adversely affect profit. As the fertilizer elasticity and irrigation in relation to profit is negative. Cost of irrigation surge by $1 \%$, decline profit by $1.136 \%$ and cost of fertilizer rise by $1 \%$ decline profit by $0.832 \%$. This is also consistent with the findings of Ullah [14]. 
Table 1. Descriptive statistics of the variables.

\begin{tabular}{cccc}
\hline Variable & Unit & Mean & Standard deviation \\
\hline Price of rice & Rs/Kg & 39.4 & 8.7 \\
Irrigation cost & Rs/acre & 21276.7 & 2932.1 \\
Price of fertilizer & Rs/Kg & 37.5 & 10.2 \\
Area under rice & Acre(s) & 8.4 & 5.6 \\
Education & Years & 2.9 & 1.46 \\
Restricted profit & Rs. & 38666.72 & 10805.01 \\
\hline
\end{tabular}

Source: Survey Data, 2011.

Table 2. Calculated elasticities and their accusation.

\begin{tabular}{ccccc}
\hline With respect to & Output price & Irrigation cost & Fertilizer price & Land \\
Output & 1.873 & -0.953 & -0.873 & 1.274 \\
Irrigation & 1.780 & -1.842 & -0.783 & 0.162 \\
Fertilizer & 1.851 & -0.851 & -1.650 & 0.144 \\
Profit & 1.920 & -1.136 & -0.832 & 0.792 \\
\hline
\end{tabular}

Source: Survey Data, 2011.

Through overall estimation, the results reveal that changes in market prices whether output or input prices effects farmer profit, rice supply and resource use. The response of farmer with changing in input or output prices was significant in the study area.

Irrigation demand elasticity in relation to fertilizer price is -0.783 , which reveals that $1 \%$ raise in the cost of fertilizer, irrigation demand decrease by $0.783 \%$. Similarly the fertilizer demand elasticity in relation to irrigation cost is also negative $-0.851,1 \%$ rises in irrigation cost, decline $0.851 \%$ demand for fertilizer. These negative elasticities show that irrigation and fertilizer are complementary inputs. Their combined application surges production synergistically.

Irrigation elasticity in relation to fixed input land is positive 1.142, which shows demand for irrigation, surge by $1.142 \%$ by increasing $1 \%$ land area. Fertilizer elasticity over the area under rice is 0.792 shows that $1 \%$ surge in the area under rice, surge demand for fertilizer by $0.792 \%$. Similarly elasticity of irrigation and fertilizer with relation to education is 0.144 and 0.023 correspondingly, which shows that the demand for the fertilizer and irrigation increases with the surge of education level of hose hold. So improving education level of the hose members, surge the demand for changeable inputs. The profit elasticity in relation to education is 0.200 , reveals that the surge of $1 \%$ of the education levels of farmers, profit increased by $0.200 \%$.

Rice supply elasticity in relation to fixed inputs land and education are positive i.e. 1.274 and 0.162 respectively. The effect of land on rice supply is significant and expansion in fixed input land, not only surge supply of rice but also profit of the farmer surges significantly. On the other hand the effect of education on rice supply and profit is positive but inelastic. This is also in agreement with the estimation of Farooq et al. [9].

\subsection{Concluding Remarks}

The analysis shows that farmers are price sensitive; that prevalence ensures equitable output and that input prices is essential for preserving the incentive for farmers ultimately surged rice production. Furthermore, application of fertilizers has surged the demand for irrigation affects positively. Surge in rice acreage significantly increases the supply of rice and profits and stimulates the demand for changeable inputs. In terms of education on the other hand, they also have positive but inelastic effects on the supply of rice, net return of the farmer and the demand for changeable inputs.

On the other hand, education level of the farming household also has a positive but inelastic effect on the supply of rice, the profit of the farmer and the demand for variable inputs. The results of the study suggest that the government should subsidize fertilizer prices to encourage its application. Increasing fertilizer application will 
not only increase output but also will encourage on-farm employment. Similarly, bringing more area under rice cultivation will increase production and the rate of the farm employment.

\section{References}

[1] Farooq, O. (2013) Agriculture. Ministry of Finance, Government of Pakistan, Islamabad.

[2] FAO (2013) Food and Agriculture Organization. Cereal Crop Statistics. http://www.fao.org/tc/tci/newsandmeetings/en/s

[3] Anonymous (2014) Basmati Rice. http://www.pakissan.com/english/allabout/crop/rice/

[4] Shaikh, F.M. and Shah, M.A. (2008) Dynamic Supply Response Analysis of Pakistani Rice Growers. Pakistan Journal of Commerce and Social Sciences, 1, 48-55.

[5] Chaudhary, M.A., Khan, M.A. and Naqvi, K.H. (1998) Estimates of Farm Output Supply and Input Demand Elasticities: The Translog Profit Function Approach. The Pakistan Development Review, 37, 1031-1050.

[6] Griffith, G., I’Anson, K., Hill, D. and Lubett, R. (2001) Previous Supply Elasticity Estimates for Australian Broadacre Agriculture.

[7] Sidhu, S.S. and Baanante, C.A. (1981) Estimating Farm-Level Input Demand and Wheat Supply in the Indian Punjab Using a Translog Profit Function. American Journal of Agricultural Economics, 63, 237-246. http://dx.doi.org/10.2307/1239559

[8] Thakare, S.S., Shende, N.V. and Shinde, K.J. (2012) Mathematical Modeling for Demand and Supply Estimation for Cotton in Maharashtra. International Journal of Scientific and Research Publications, 2, 1-5.

[9] Farooq, U., Young, T., Russell, N. and Iqbal, M. (2001) The Supply Response of Basmati Rice Growers in Punjab, Pakistan: Price and Non-Price Determinants. Journal of International Development, 13, 227-237. http://dx.doi.org/10.1002/jid.728

[10] Diewert, W.E. (1974) () Applications of Duality Theory. In: Intrlligator, M.D. and Kendrick, D.A., Eds., Frontiers of Qumtitatiue Economics, Stanford Institute for Mathematical Studies in the Social Sciences, North-Holland Publishing Company, Amsterdam.

[11] Christensen, L.R., Jorgenson, D.W. and Lau, L.J. (1973) Transcendental Logarithmic Production Frontiers. The Review of Economics and Statistics, 55, 28-45. http://dx.doi.org/10.2307/1927992

[12] Gujarati, D.N. (2012) Basic Econometrics. Tata McGraw-Hill Education, Noida.

[13] Rahman, S. (2003) Profit Efficiency among Bangladeshi Rice Farmers. Food Policy, 28, 487-503. http://dx.doi.org/10.1016/j.foodpol.2003.10.001

[14] Ullah, R., Ali, S., Safi, Q.S., Shah, J. and Khan, K.H. (2012) Supply Response Analysis of Wheat Growers in District Peshawar: Pakistan. International Journal of Latest Trends in Agriculture and Food Sciences, 2, 33-38. 
Scientific Research Publishing (SCIRP) is one of the largest Open Access journal publishers. It is currently publishing more than 200 open access, online, peer-reviewed journals covering a wide range of academic disciplines. SCIRP serves the worldwide academic communities and contributes to the progress and application of science with its publication.

Other selected journals from SCIRP are listed as below. Submit your manuscript to us via either submit@scirp.org or Online Submission Portal.
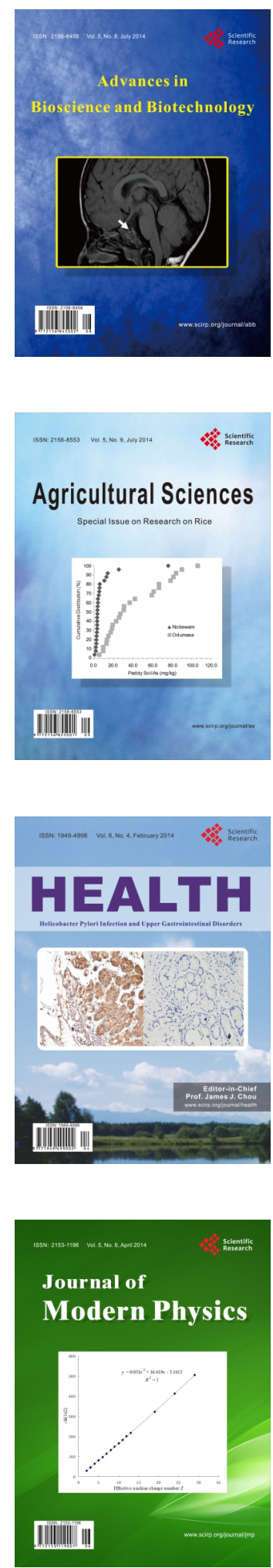
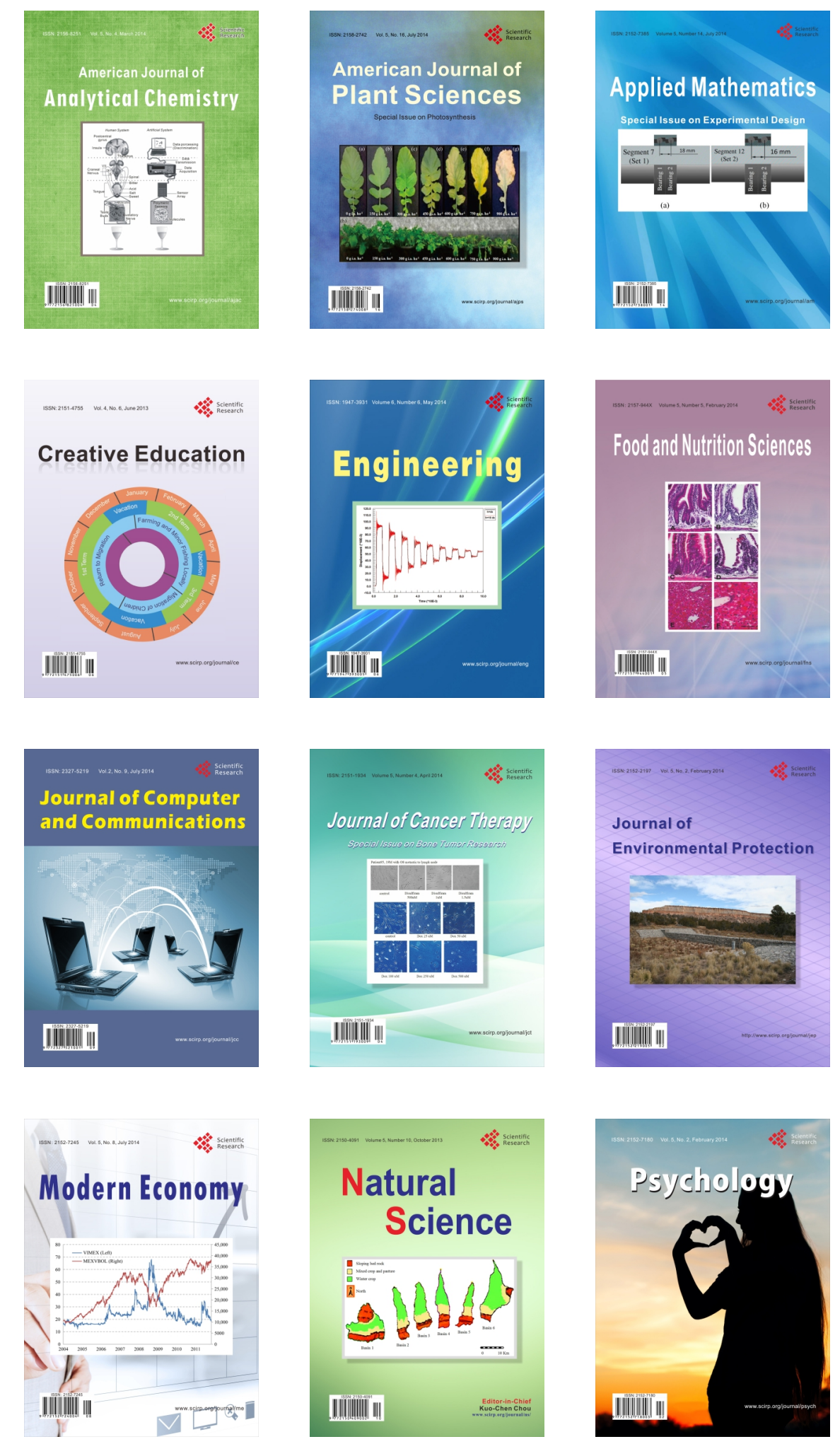